\title{
Cold-induced growth arrest in gilthead sea bream Sparus aurata: metabolic reorganisation and recovery
}

\author{
Sergio Sánchez-Nuño ${ }^{1}$, Orhan Tufan Eroldogan ${ }^{2}$, Ignasi Sanahuja ${ }^{1}$, \\ Ilgın Özşahinoğlu ${ }^{3}$, Josefina Blasco ${ }^{1}$, Jaume Fernández-Borràs ${ }^{1}$, \\ Ramon Fontanillas ${ }^{4}$, Pedro M. Guerreiro ${ }^{5}$, Antoni Ibarz ${ }^{1, *}$ \\ ${ }^{1}$ Department of Cellular Biology, Physiology and Immunology, Faculty of Biology, Universitat de Barcelona, \\ Avda. Diagonal 643, 08028 Barcelona, Spain \\ ${ }^{2}$ Faculty of Fisheries, Department of Aquaculture, University of Çukurova, 01330 Adana, Turkey \\ ${ }^{3}$ Feke Vocational School, University of Çukurova, 01330 Adana, Turkey \\ ${ }^{4}$ Skretting Aquaculture Research Centre (ARC), PO Box 48, 4001 Stavanger, Norway \\ ${ }^{5}$ Centro de Ciências do Mar, CCMAR, University of Algarve, Campus de Gambelas, 8005-139 Faro, Portugal
}

\begin{abstract}
There are currently no standard diets or practices to counteract or ameliorate the growth arrest and extremely poor feed conversion rates (FCR) in gilthead sea bream Sparus aurata caused by low water temperatures. The present study analysed the effects of reducing dietary lipid content from 18 to $14 \%$ during a temperature fluctuation period. Temperature was gradually reduced from $22^{\circ}$ to $14^{\circ} \mathrm{C}$ over a period of $5 \mathrm{~d}$, and maintained at this low temperature for a further $45 \mathrm{~d}$ before gradual recovery over $7 \mathrm{~d}$ to $22^{\circ} \mathrm{C}$ under controlled conditions, avoiding other stressors often present in cage culture conditions. Decreasing dietary lipid content at an elevated temperature $\left(22^{\circ} \mathrm{C}\right)$ did not significantly affect the standard growth rate or FCRs of the sea bream, indicating a possibility to reduce the dietary energy during the months before winter. Although cold-induced growth arrest and metabolic depression were unavoidable, a well-formulated, lowlipid diet adequately met the low energy demands at low temperatures. Analysis of plasma metabolites and liver enzyme activities demonstrated a reorganisation of liver metabolism, mainly in fish on a low-lipid diet. Recovery from low temperatures was delayed, with a higher dietary lipid content required for optimal liver condition, and mineral supplementation to maintain osmoregulation and bone formation. Our results provide useful information for fish producers and researchers, suggesting that dietary lipid contents should be reduced to allow fish to better cope with low temperatures, and that improved diets with higher lipid content are required for recovery from low temperatures.
\end{abstract}

KEY WORDS: Cold challenge $\cdot$ Dietary lipid $\cdot$ Metabolism $\cdot$ Osmoregulation $\cdot$ Sparus aurata

\section{INTRODUCTION}

Fish from temperate latitudes are usually exposed to broad fluctuations in water temperatures. However, when such variations exceed the thermal tolerance range of the species, the consequences can be highly deleterious or even fatal. Acute drops in water

*Corresponding author: tibarz@ub.edu

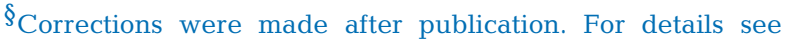
www.int-res.com/abstracts/aei/v10/c_p511-528/

This corrected version: January 9, 2019 temperature or persistent low temperatures during the winter often cause 'winter mortalities', a phenomenon that has been reported for a large number of fish species (Hurst 2007). Acute thermal stress and starvation have traditionally been linked to mortalities in overwintering wild fish populations (Donaldson et al. 2008), with accumulating evidence addi-

(C) The authors 2018. Open Access under Creative Commons by Attribution Licence. Use, distribution and reproduction are unrestricted. Authors and original publication must be credited. 
tionally indicating that susceptibility to disease and handling disturbances in cultured species are also related to low temperatures (Toranzo et al. 2005, Ibarz et al. 2010a).

Gilthead sea bream Sparus aurata is one of the most common marine species in the Mediterranean Sea and one of the most consumed seafood species in Europe. Its lower temperature limit is around $5^{\circ} \mathrm{C}$ (Ravagnan 1978, Barnabé 1990), but a drastic reduction in food intake has been observed at temperatures below $13^{\circ} \mathrm{C}$, greatly affecting fish production (Tort et al. 1998, Sarusic 1999). The reduced food intake at low temperatures has also been observed under laboratory controlled conditions. For example, sea bream individuals have been reported to stop feeding below $13^{\circ} \mathrm{C}$ (Ibarz et al. 2003) and not resume feeding during extended periods of constantly low temperatures, such as during $20 \mathrm{~d}$ at $12^{\circ} \mathrm{C}$ or $35 \mathrm{~d}$ at $8^{\circ} \mathrm{C}$ (Ibarz et al. 2007a,b). Although natural fasting is common during the cold season for several fish species, this produces economic losses in fish farming. Determining the mechanisms underlying food acceptance and its effects on starved fish could be important in enhancing fish production during the cold season. Furthermore, growth arrest may persist even after water temperatures start to rise in the spring, as feeding and feed conversion efficiency do not immediately recover in both indoor and culture conditions (reviewed in Ibarz et al. 2010a).

There is a lack of understanding regarding the origin of cold-induced growth arrest and the physiological changes that occur during the cold season. Moreover, there are currently no specific diets for cultured fish in the winter period. Several attempts have been made to prepare fish for winter conditions, such as trying to enhance their nutritional status mainly during and after the cold season. In indoor culture facilities, Ibarz et al. (2007a) studied the recovery of sea bream after prolonged exposure to a low temperature $\left(8^{\circ} \mathrm{C}\right)$, fasting at a warm temperature $\left(18^{\circ} \mathrm{C}\right)$ and during temperature fluctuations in relation to the growth parameters, metabolic rates and liver composition of fed animals at a warm temperature $\left(18^{\circ} \mathrm{C}\right)$. Although the effects of fasting were delayed by low temperatures, changes were observed such as hepatic glycogen mobilisation, digestive membrane degeneration and the export of amino acids from muscle tissues. Moreover, the improvement during transient warm periods promoted fish health by minimising cold-induced arrested growth and hepatic alterations, such as lipid deposition in the liver. Furthermore, short periods of re-feeding resulted in lower expenditure on tissue repair, with the growth rate recovering earlier than under sustained cold conditions. Tort et al. (2004) observed that an enhanced dietary formulation (more palatable and supplemented with vitamins and minerals, as well as containing higher amounts of digestible proteins and unsaturated lipids) produced some improvement in the immune status of sea bream at a low temperature $\left(11^{\circ} \mathrm{C}\right)$. Likewise, Silva et al. (2014) reported that a diet enriched with raw materials, such as fish meal and krill meal, enhanced fish performance during a natural temperature regime when compared to a low-cost commercial formulation. In our view, current commercial fat-enriched diets should not be recommended for pre-winter and winter periods (Ibarz et al. 2010a). Recent studies have demonstrated that dietary energy levels and culture density negatively correlate with growth performance and metabolic and oxidative statuses (Suárez et al. 2015).

The present study analysed the effects of reducing dietary lipid content on gilthead sea bream during a temperature fluctuation period simulating the temperature changes that occur during the winter. The temperature was reduced to $14^{\circ} \mathrm{C}$, maintained at this temperature and then restored to $22^{\circ} \mathrm{C}$ under controlled conditions. In this way, associated stressors such as storms, crowding or infections, that are often present in cage culture conditions were avoided and valuable data on growth performance, osmoregulation and liver intermediary metabolism of the fish could be obtained. To assess the effects of the controlled temperature fluctuation, we analysed fish weight gain, food intake, growth indices and feed conversion rates, as well as plasma biochemistry, branchial and intestinal $\mathrm{Na}^{+} / \mathrm{K}^{+}$-ATPase activities and the activities of key enzymes associated with liver metabolism. Plasma biochemistry parameters indicate the nutritional status of healthy juvenile gilthead sea bream (Peres et al. 2013), with the plasma levels of glucose, lactate, protein and lipid fractions strongly correlating with low temperatures in this species (reviewed in Ibarz et al. 2010a). Osmoregulation is also influenced by low temperatures, with food deprivation in euryhaline species showing seasonal dependence in culture conditions (Sangiao-Alvarellos et al. 2003, Polakof et al. 2006). Finally, liver intermediary metabolism was assessed by studying the activities of the enzymes glucose-6-phosphate dehydrogenase (G6PDH), lactate dehydrogenase (LDH), hydroxyacyl-CoA dehydrogenase (HOAD), aspartate aminotransferase (AST), alanine aminotransferase $(\mathrm{ALT})$, glutamate dehydrogenase $(\mathrm{GDH})$, citrate synthase (CS) and cytochrome-C oxidase (COX), focus- 
ing on their recovery from low temperatures, their temperature coefficients $\left(Q_{10}\right)$ and the enzyme ratios as indicators of metabolic reorganisation.

\section{MATERIALS AND METHODS}

\section{Rearing conditions, experimental diets, design and sampling}

Gilthead sea bream from a local fish farm, with an average body weight of $145 \mathrm{~g}$, were acclimated indoors at the Centre d'Aquicultura (CA-IRTA, Sant Carles de la Ràpita, Tarragona, Spain) at $22^{\circ} \mathrm{C}$ for 2 wk, using a standard commercial fish feed. The initial weight was selected to match the typical weight of sea bream affected by the cold season under culture conditions: 100-400 $\mathrm{g}$ (reviewed in Ibarz et al. 2010a). Moreover, the experiment was started in November to mimic the photoperiod of the cold season in cultures. Following this period, the fish were randomly distributed into 3 experimental groups per triplicate (30 fish tank ${ }^{-1}$ ) into a water recirculating system, IRTAmar ${ }^{\mathrm{TM}}$. Fifteen 5001 fibreglass tanks were used that were supported by solid and biological filters, maintaining nitrite, nitrate and ammonia concentrations at initial levels throughout the experimental period. Water temperature and oxygen concentration were closely monitored. Three isoprotein (47\% of crude protein) diets were obtained from the Skretting Aquaculture Research Centre that differed only in their lipid content: $14 \%$ (D14 diet), 16\% (D16 diet) and $18 \%$ (D18 diet), with a corresponding 'crude energy' of 20.2, 20.6 and 21.0 $\mathrm{MJ} \mathrm{kg}^{-1}$ of dry matter, respectively. Fish were fed to satiation twice a day, $7 \mathrm{~d} \mathrm{wk}^{-1}$ for $115 \mathrm{~d}$. Feed was automatically delivered (30 min) at 08:00 and 16:00 h. Satiation was ensured throughout the experimental period by calculating the estimated daily feed intake and providing a ration that was $20 \%$ above this value. Feed delivery was recorded daily, with the uneaten feed collected daily by the system and then manually dried and weighed to calculate the actual feed intake.
The total experimental period (115 d) consisted of 3 periods: the 'Pre-cold' period (PC), during which the temperature was at $22^{\circ} \mathrm{C}$ for $30 \mathrm{~d}$; the 'Cold' period (C), during which the temperature was cooled to $14^{\circ} \mathrm{C}$ over $5 \mathrm{~d}$ and maintained at this temperature for $45 \mathrm{~d}$ (50 d in total); and the 'Recovery' period, during which the temperature was increased to $22^{\circ} \mathrm{C}$ over $7 \mathrm{~d}$ and maintained for $28 \mathrm{~d}$ at $22^{\circ} \mathrm{C}(35 \mathrm{~d}$ in total) (Fig. 1). The total biomass from the triplicate tanks was recorded at the end of each period (Days 30,80 and 115) to evaluate weight gain and the feed conversion rate $\left(\mathrm{FCR}_{\text {; }}\right.$ feed intake fish ${ }^{-1} /$ increase in biomass). To monitor growth, the weight and length of the fish from each tank were individually measured at Day 0 and at the end of each temperature period. The specific growth rates (SGR) of each tank were calculated as follows: $\operatorname{SGR}\left(\% \mathrm{~d}^{-1}\right)=100 \times\left(\ln W_{\mathrm{f}}\right.$ - $\left.\ln W_{\mathrm{i}}\right) / t$, where $W_{\mathrm{i}}$ and $W_{\mathrm{f}}$ are the initial and final biomass, respectively, and $t$ is the number of days (period).

For the metabolic study, 3 fish from each tank (9 fish for each group) were captured at random from each dietary condition and anaesthetised with 2phenoxyethanol (100 ppm) diluted in seawater. Sam-

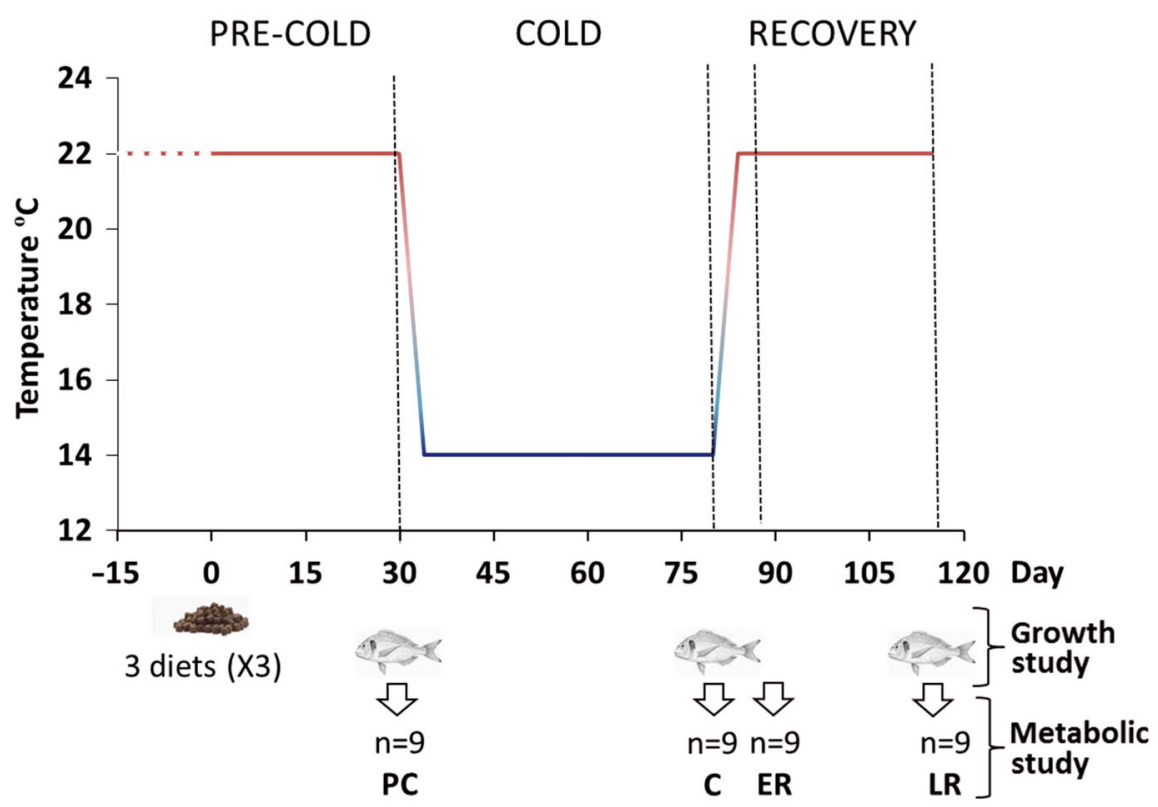

Fig. 1. Experimental design; experimental period (115 d) consisted of 3 temperature periods: the Pre-Cold (PC) period, during which the temperature was at $22^{\circ} \mathrm{C}$ for $30 \mathrm{~d}$; the Cold (C) period, during which the temperature was cooled to $14^{\circ} \mathrm{C}$ over $5 \mathrm{~d}$ and maintained for another $45 \mathrm{~d}(50 \mathrm{~d}$ total); and the recovery period (including Early Recovery, ER, and Late Recovery, LR), during which the temperature was raised to $22^{\circ} \mathrm{C}$ over $7 \mathrm{~d}$ and maintained for another $28 \mathrm{~d}$ ( $35 \mathrm{~d}$ total). The gilthead sea bream growth study was performed using the total biomass of each individual tank ( $3 \times$ diet) from Days 30, 80 and 115. The metabolic study was performed using 9 fish (3 fish per replicate tank in each diet). Fish symbols: sampling times and the number of fish (n) $\operatorname{diet}^{-1}$ 
pling was performed during the $\mathrm{PC}$ and $\mathrm{C}$ periods, as well as on Day 87 (for Early Recovery, ER) and Day 115 (for Late Recovery, LR) during the recovery period (Fig. 1). Fish were fasted for $24 \mathrm{~h}$ before sampling. Body weight and length were individually measured, and blood samples were taken from the caudal vessels using EDTA-Li as the anticoagulant. The fish were sacrificed by severing the spinal cord. Plasma was obtained by centrifuging the blood at $13000 \times g$ at $4^{\circ} \mathrm{C}$ for $5 \mathrm{~min}$, and stored at $-80^{\circ} \mathrm{C}$ until analysis. The weights of the perivisceral fat (the white adipose mass surrounding the gut) and the liver were also recorded. Liver samples were immediately frozen in liquid $\mathrm{N}_{2}$ and stored at $-80^{\circ} \mathrm{C}$. Gill and intestinal samples were placed in ice-cold sucrose-EDTA-imidazole (SEI) buffer (150 mM sucrose, $10 \mathrm{mM}$ EDTA and $50 \mathrm{mM}$ imidazole, pH 7.3) and frozen at $-80^{\circ} \mathrm{C}$. The study complied with the guidelines of the European Union (86/609/EU), the Spanish Government (RD 1201/2005) and the University of Barcelona (Spain) regarding the use of laboratory animals.

\section{Osmolality, electrolytes and gill and intestinal $\mathrm{Na}^{+} / \mathrm{K}^{+}$-ATPase activities}

Plasma osmolality (mOsm $\mathrm{kg}^{-1}$ ) was measured with a vapour pressure osmometer (Wescor Vapro 5520). Plasma concentrations of sodium and potassium were determined in duplicate heatdenatured pre-diluted plasma samples, using a BWB XP flame photometer (BWB Technologies). Chloride and phosphorus concentrations were determined with endpoint colorimetric assays (commercial kits from Spinreact), modified for microtiter plates and measured in a Benchmark microplate reader (Bio-Rad Laboratories). Gill and intestinal $\mathrm{Na}^{+} / \mathrm{K}^{+}$-ATPase activity was determined using the microassay method (McCormick 1993) modified for gilthead sea bream (Mancera et al. 2002), in which samples were homogenised in $125 \mathrm{ml}$ of SEI buffer with $0.1 \%$ deoxycholic acid and then centrifuged at $2000 \times g$ for $30 \mathrm{~s}$. The homogenate extracts were then added to the assay mixture in the presence or absence of $0.5 \mathrm{mM}$ ouabain in 96-well microplates at $25^{\circ} \mathrm{C}$ and read at $340 \mathrm{~nm}$ for $10 \mathrm{~min}$ with intermittent stirring by vibration in a Benchmark microplate reader (Bio-Rad Laboratories). Ouabain-sensitive ATPase activity was detected by the enzymatic coupling of ATP dephosphorylation to NADH oxidation and expressed in $\mu$ mol ADP $\mathrm{mg}^{-1}$ protein $\mathrm{h}^{-1}$.

\section{Plasma metabolites and liver enzyme activities}

Plasma levels of glucose, lactate, triacylglycerides (TAG), phospholipids (PL), total cholesterol (TC) and non-esterified fatty acids (NEFA) were analysed with respective commercial kits (Spinreact and Wako Chemicals). Metabolites were measured in triplicate in pre-diluted plasma samples when necessary, using an endpoint colorimetric assay and each internal standard of the respective kit. Protein concentrations in the plasma were measured using the method of Bradford \& Williams (1976) with bovine serum albumin used as a standard. Plasma concentrations are expressed in $\mathrm{mM}$ (glucose and lactate), $\mathrm{mg}$ of lipid fraction $\mathrm{dl}^{-1}$ (TAG, PL, TC and NEFA) or $\mathrm{mg} \mathrm{l}^{-1}$ (protein). Total lipid levels in the plasma were obtained by the sum of the lipid fractions.

Liver samples for enzyme assays were pulverised in liquid nitrogen and homogenised in 9 volumes of icecold lysis buffer (1.24 mM Triton X-100, 1 mM EDTA and $1 \mathrm{mM} \mathrm{NaHCO}$ ) with stabilising solution (37 mM EDTA and 5 mM 2- $\beta$-mercaptoethanol), 1:1 v/v, as described in Blasco et al. (2015). Corresponding homogenates for measuring cytoplasmic enzyme activities were centrifuged at $3000 \times g$ at $4^{\circ} \mathrm{C}$ for $10 \mathrm{~min}$, while homogenates for measuring mitochondrial enzyme activities were centrifuged at $1000 \times g$ at $4^{\circ} \mathrm{C}$ for $10 \mathrm{~min}$. The resulting supernatants were aliquoted and stored at $-80^{\circ} \mathrm{C}$ until analysis. The respective commercial kits (Spinreact) to measure AST, ALT, LDH and G6PDH activities were adapted for sea bream liver measurements from the respective commercial kits (Spinreact). Analyses of CS and COX activities were performed following the method described by Srere (1969) that was adapted for sea bream by Martin-Perez et al. (2012). GDH and HOAD activities were analysed using the methods adapted for sea bream as reported by Furné et al. (2009). All enzyme assays were carried out at $25^{\circ} \mathrm{C}$ using a UV/Vis spectrophotometer (Infinity 200Pro) and were run in duplicate in semi-micro cuvettes. The optimal substrate and protein concentrations for measuring enzyme activities were preliminarily assayed. The change in absorbance of NADH and NADP at $340 \mathrm{~nm}$ and the reduction of DTNB at $412 \mathrm{~nm}$ were monitored. The millimolar extinction coefficients used were 6.22 for NADH and NADP and 13.6 for DTNB (5,5'-dithio-bis-[2-nitrobenzoic acid]). COX activity was determined by the decrease in ferrocytochrome $c$ absorbance at $550 \mathrm{~nm}$. Enzyme activities are reported in milliunits (nmol of substrate transformed $\mathrm{min}^{-1}$ ) $\mathrm{mg}^{-1}$ of fresh liver weight $\left(\mathrm{mIU} \mathrm{mg}^{-1}\right.$ fw). Temperature coefficients $\left(Q_{10}\right)$ were calculated as the thermal sensitivity of the enzyme activities be- 
tween the temperature periods of the study, using the formula provided by Prosser (1991):

$$
Q_{10}=\left(K_{2} / K_{1}\right)^{10\left(T_{2}-T_{1}\right)}
$$

where $K_{1}$ and $K_{2}$ are the mean enzyme activity at temperatures $T_{1}$ and $T_{2}$, respectively.

\section{Statistical analysis}

Statistical differences (1) throughout the temperature periods within each diet and (2) between the diets were analysed by a 1-way nested analysis of variance (ANOVA), with tank as the random factor to test for a possible effect. A tank effect was not found. Thus, an ANOVA followed by Tukey's or Dunnett's post hoc test was conducted when variances were uniform or not, respectively. Statistical differences were considered significant when p-values were less than 0.05. The Shapiro-Wilk test was first used to ensure the normal distribution of the data, while Levene's test was applied to check the uniformity of the variances. All statistical analyses were performed using commercial software (PASW 20.0; SPSS).

\section{RESULTS}

\section{Effects of temperature fluctuation on growth performance}

Growth performance and feed parameters are summarised in Table 1, which compares each diet during the 3 temperature periods and all the diets within each

Table 1. Effects of dietary lipid contents (D14, D16 and D18: diets containing 14, 16 and 18\% lipid content, respectively) on gilthead sea bream growth and feed parameters throughout the temperature periods. Growth parameters are expressed as mean $\pm \mathrm{SE}$, and were obtained from the total biomass of each individual tank ( $\mathrm{n}=3 \mathrm{diet}^{-1}$ ). Initial body weight (BW) (Day 0) was $145 \pm 0.1 \mathrm{~g}$, initial body length (BL) was $17.3 \pm 0.0 \mathrm{~cm}$ and initial condition factor was $2.90 \pm 0.01$. CF: condition factor; SGR: standard growth rate; FCR: feed conversion rate. HSI: hepatosomatic index and MFI: mesenteric fat index were calculated from the fish $(n=9)$ sampled for the metabolic study. Significant differences between temperature periods within each diet are indicated by lowercase letters; 'Diet effect' or significant differences between diets during each period are indicated by capital letters (Tukey's post hoc $\mathrm{p}<0.05$, or Dunnett's post hoc $\mathrm{p}<0.05$ only for MFI data)

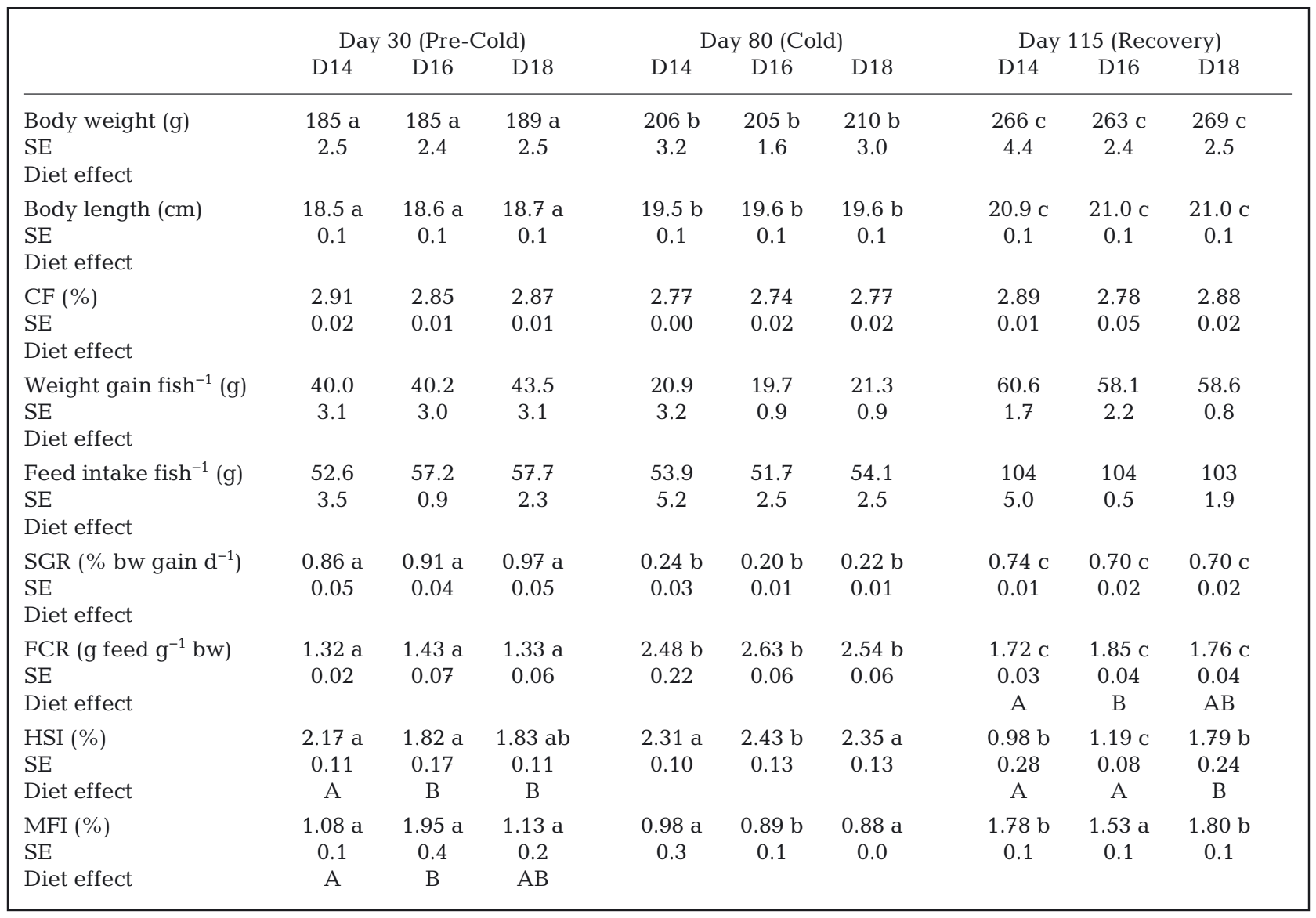


period (diet effect). During the PC period, decreasing dietary lipid content from 18 to $14 \%$ at $22^{\circ} \mathrm{C}$ did not significantly affect sea bream body weight, body length or condition factor. Accordingly, weight gain and the SGRs did not differ, although the SGRs appeared to increase with higher dietary lipid contents. Other body indices, such as the hepatosomatic index (HSI) and the mesenteric fat index (MFI), showed significant differences, with the HSI and MFI being the highest in D14and D16-fed fish, respectively (Tukey, $\mathrm{p}<0.05$ ).

The drop in water temperature to $14^{\circ} \mathrm{C}$ and the maintenance of this temperature (50 d in total) drastically reduced daily growth and hampered food conversion. Thus, the growth arrest induced by the low temperature of $14^{\circ} \mathrm{C}$ was evidenced by the drastic reduction in the SGRs (around 4 -fold) and the doubling of the FCRs, with the condition of the D14-fed fish being the least affected. In parallel, the cold challenge increased the HSI significantly (Tukey, $\mathrm{p}<$ 0.05 ) for the fish on the D16 diet, with a concomitant mobilisation of mesenteric fat (Dunnett, $\mathrm{p}<0.05$ ). At the end of the recovery period (Day 115), there were no significant differences in the final body weight between the different diets. However, growth performance was not completely restored, with the SGRs from the recovery period being lower (between $0.70-0.74$ body weight [BW] gain $\mathrm{d}^{-1}$ ) than those from the PC period, and the FCR values still being higher (between 1.72-1.85 $\mathrm{g}$ feed $\mathrm{g}^{-1} \mathrm{BW}$ ). The main difference between the fish on the different diets was observed in the HSI values, which were restored in D18-fed fish, but significantly reduced in the D14and D16-fed fish compared to the D18-fed fish (Tukey, $\mathrm{p}<0.05$ ) and the PC values (35 and 55\%, respectively; Tukey, $\mathrm{p}<0.05)$.

\section{Effects of temperature fluctuation on plasma metabolites}

The plasma levels of glucose, lactate, protein and lipid fractions (Table 2) were measured after over-

Table 2. Plasma metabolites in juvenile sea bream feeding on diets with different lipid contents (D14, D16 and D18: 14, 16 and $18 \%$ lipids respectively) throughout the temperature fluctuation. Data are expressed as mean \pm SE. Significant differences between the periods within each diet are indicated by lowercase letters (Tukey's post hoc $p<0.05$, or Dunnett's post hoc $p<0.05$ only for 'sum of lipids' data); significant differences between the diets during each period are indicated by capital letters (Tukey's post hoc $\mathrm{p}<0.05$, or Dunnett's post hoc $\mathrm{p}<0.05$ only for 'sum of lipids' data). NEFA: non-esterified fatty acids; TAG: triacylglycerides; TC: total cholesterol; PL: phospholipids

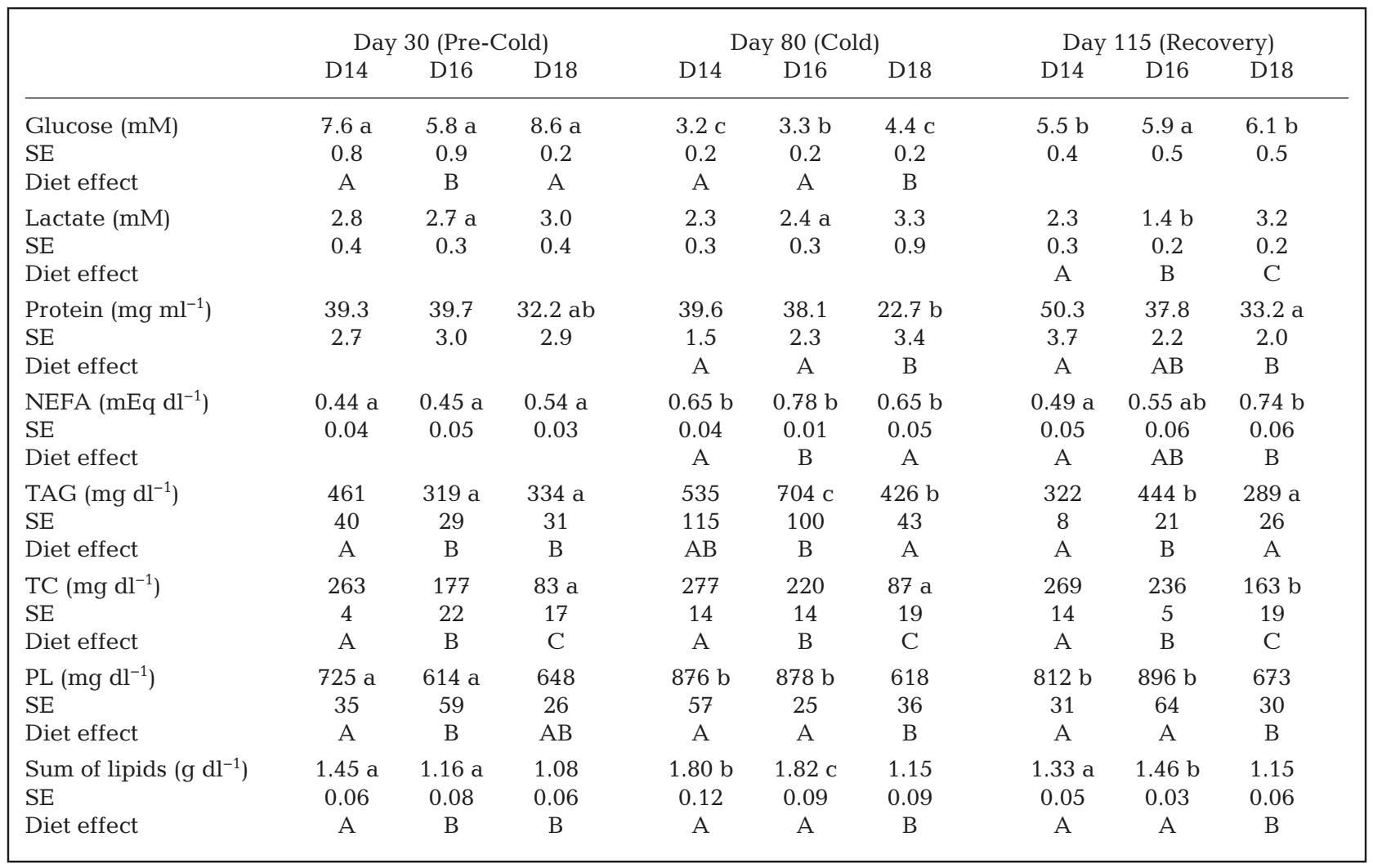


night fasting and corresponded to basal levels before the intake of the morning ingesta. Circulating lipid fractions, TAG, TC and PL were significantly higher in D14-fed fish, producing a $40 \%$ increase in lipaemia (expressed as the 'sum of plasma lipids'), than in D18-fed fish $\left(1.45 \pm 0.06 \mathrm{~g} \mathrm{dl}^{-1}\right.$ for D14 vs. $1.08 \pm$ $0.06 \mathrm{~g} \mathrm{dl}^{-1}$ for D18; Dunnett, $\left.\mathrm{p}<0.05\right)$. Differences in glycaemia between the diets during the PC period did not correspond to dietary energy levels. Other plasma metabolites, such as lactate, total protein and NEFAs, did not differ between the diets. During the C period, glycaemia was reduced 2-fold, irrespective of diet, while hyperlipaemia was observed in the fish on the D14 and D16 diets and hypoproteinaemia in those on the D18 diet. At the end of the recovery period, most of the plasma metabolites were restored to their PC levels, except glucose. See Fig. 4 for a summary of the changes in plasma metabolites in response to temperature fluctuations, illustrating that the differences in plasma metabolite levels between the diets were maintained throughout the whole experimental period whereas the effects of temperature were transitory, although the SGRs and FCRs were partially reverted, and the HSI for D16-fed and D14fed fish indicated delayed recovery in these animals.

\section{Effects of temperature fluctuation on osmoregulation}

Plasma osmolality, plasma ions (sodium, chloride, potassium and phosphorus) and gill and intestinal (proximal section) $\mathrm{Na}^{+} / \mathrm{K}^{+}$-ATPase activities were also measured to evaluate the effects of a low temperature and temperature recovery on the osmoregulatory capacity of sea bream (Table 3 ). The highest osmolality values (around $500 \mathrm{mOsm} \mathrm{kg}^{-1}$ ) were recorded during the PC period, irrespective of diet, and were significantly reduced (Tukey, p < 0.05) at the end of both the cold and recovery periods (to around $450 \mathrm{mOsm} \mathrm{kg}{ }^{-1}$ ). The fish on the D14 diet showed higher PC levels of sodium and chloride than those on the D16 and D18 diets (Tukey, p < 0.05). However, the sum of the sodium plus chloride ions

Table 3. Osmoregulation-related parameters in juvenile sea bream feeding on diets with different lipid contents (D14, D16 and D18: 14,16 and $18 \%$ lipids respectively) throughout the temperature fluctuation. Data are expressed as mean \pm SE; ATPase activities are expressed as $\mu \mathrm{gADP} \mathrm{mg}^{-1}$ protein $\mathrm{h}^{-1}$. Significant differences between the periods within each diet are indicated by lowercase letters; significant differences between the diets during each period are indicated by capital letters (Tukey's post hoc, $\mathrm{p}<0.05$ )

\begin{tabular}{|c|c|c|c|c|c|c|c|c|c|}
\hline & \multicolumn{3}{|c|}{ Day 30 (Pre-Cold) } & \multicolumn{3}{|c|}{ Day 80 (Cold) } & \multicolumn{3}{|c|}{ Day 115 (Recovery) } \\
\hline & D14 & D16 & D18 & D14 & D16 & D18 & D14 & D16 & $\mathrm{D} 18$ \\
\hline \multicolumn{10}{|l|}{ Plasma } \\
\hline Osmolality (mOsm kg-1) & $507 \mathrm{a}$ & $512 \mathrm{a}$ & $482 \mathrm{a}$ & $435 \mathrm{~b}$ & $442 \mathrm{~b}$ & $436 \mathrm{~b}$ & $416 \mathrm{~b}$ & $437 \mathrm{~b}$ & $438 \mathrm{~b}$ \\
\hline $\mathrm{SE}$ & 11.4 & 10.7 & 8.1 & 7.3 & 11.5 & 8.5 & 7.0 & 8.9 & 13.0 \\
\hline \multicolumn{10}{|l|}{ Diet effect } \\
\hline Sodium (mM) & 220.8 a & $198.2 \mathrm{a}$ & $180.1 \mathrm{a}$ & $174.1 \mathrm{C}$ & $170.4 \mathrm{~b}$ & $170.7 \mathrm{~b}$ & $192.6 \mathrm{~b}$ & $204.8 \mathrm{a}$ & $197.7 \mathrm{a}$ \\
\hline SE & 7.12 & 8.81 & 5.28 & 3.53 & 3.68 & 7.44 & 4.6 & 5.60 & 3.78 \\
\hline Diet effect & $\mathrm{A}$ & $\mathrm{AB}$ & B & & & & & & \\
\hline Chloride (mM) & $159.0 \mathrm{a}$ & $147.9 \mathrm{a}$ & $147.8 \mathrm{a}$ & $121.2 \mathrm{~b}$ & $121.9 \mathrm{~b}$ & $119.6 \mathrm{~b}$ & $125.1 \mathrm{~b}$ & $119.7 \mathrm{~b}$ & $118.0 \mathrm{~b}$ \\
\hline SE & 1.96 & 2.77 & 1.89 & 2.46 & 3.40 & 3.20 & 2.74 & 2.41 & 1.64 \\
\hline Diet effect & $\mathrm{A}$ & $\mathrm{B}$ & $\mathrm{B}$ & & & & & & \\
\hline Potassium (mM) & $2.70 \mathrm{a}$ & $2.40 \mathrm{a}$ & 3.04 & $3.01 \mathrm{ab}$ & $2.98 \mathrm{a}$ & 2.95 & $3.59 \mathrm{~b}$ & $4.00 \mathrm{~b}$ & 3.72 \\
\hline $\mathrm{SE}$ & 0.202 & 0.275 & 0.196 & 0.239 & 0.228 & 0.300 & 0.191 & 0.148 & 0.099 \\
\hline \multicolumn{10}{|l|}{ Diet effect } \\
\hline Phosphorus (mM) & $3.15 \mathrm{a}$ & $3.47 \mathrm{a}$ & $3.37 \mathrm{a}$ & $2.85 \mathrm{ab}$ & $2.85 \mathrm{~b}$ & $2.82 \mathrm{~b}$ & $2.45 \mathrm{~b}$ & $2.50 \mathrm{C}$ & $2.30 \mathrm{C}$ \\
\hline SE & 0.166 & 0.129 & 0.194 & 0.108 & 0.060 & 0.137 & 0.091 & 0.091 & 0.098 \\
\hline \multicolumn{10}{|l|}{ Diet effect } \\
\hline \multicolumn{10}{|l|}{$\mathrm{Na}^{+} / \mathbf{K}^{+}$-ATPase activity } \\
\hline Branchial & 3.37 & 2.90 & 2.18 & 3.52 & 1.91 & 1.74 & 1.29 & 2.64 & 1.68 \\
\hline $\mathrm{SE}$ & 0.442 & 0.672 & 0.735 & 1.090 & 0.438 & 0.281 & 0.672 & 0.600 & 0.183 \\
\hline \multicolumn{10}{|l|}{ Diet effect } \\
\hline Intestinal & 12.36 & $33.89 \mathrm{a}$ & 26.42 & 21.42 & $36.93 \mathrm{a}$ & 17.39 & 8.74 & $15.57 \mathrm{~b}$ & 20.73 \\
\hline $\mathrm{SE}$ & 2.942 & 7.73 & 3.917 & 5.642 & 5.095 & 3.787 & 2.642 & 5.121 & 6.360 \\
\hline Diet effect & $\mathrm{A}$ & B & $\mathrm{AB}$ & $\mathrm{AB}$ & B & A & & & \\
\hline
\end{tabular}


could not explain the higher values of osmolality for any of the diets. Plasma potassium $(2.5-3.0 \mathrm{mM})$ and phosphorus (3.0-3.5 mM) levels were not affected by diet during the $\mathrm{PC}$ period $\left(22^{\circ} \mathrm{C}\right)$. The low temperature of $14^{\circ} \mathrm{C}$ significantly reduced (Tukey, $\mathrm{p}<0.05$ ) plasma chloride and phosphorus levels for all the 3 diets, and sodium levels for the D14 and D16 diets. Although plasma sodium levels reverted during the recovery period, plasma chloride levels did not increase, while plasma phosphorus levels were even lower. Curiously, plasma potassium levels significantly increased from $3.0 \mathrm{mM}$ to $3.5-4.0 \mathrm{mM}$ (Tukey, $\mathrm{p}<0.05$ ).

While $\mathrm{Na}^{+} / \mathrm{K}^{+}$-ATPase activities were not significantly affected by the cold challenge, plasma ion concentrations were lower during the Cold period and only partially reverted during the recovery period, irrespective of diet. Both branchial and intestinal $\mathrm{Na}^{+} / \mathrm{K}^{+}$-ATPase activities were evaluated during the temperature fluctuation. Despite higher variance, intestinal $\mathrm{Na}^{+} / \mathrm{K}^{+}$-ATPase activity was lower in D14-fed fish than in D16- and D18-fed fish. Diet did not affect branchial $\mathrm{Na}^{+} / \mathrm{K}^{+}$-ATPase activity. Branchial and intestinal $\mathrm{Na}^{+} / \mathrm{K}^{+}$-ATPase activities were not affected by the $\mathrm{C}$ period, with only intestinal $\mathrm{Na}^{+} / \mathrm{K}^{+}$-ATPase activity in the D16-fed fish being significantly reduced during the recovery period (Tukey, p < 0.05).

\section{Effects of temperature fluctuation on liver enzyme activities}

The activities of key enzymes associated with the pentose shunt (G6PDH), the glycolytic pathway (LDH), aerobic metabolism (CS and COX), $\beta$-oxidation (HOAD) and protein catabolism (ALT, AST and GDH) are shown in Fig. 2. To better understand the recovery process, sampling was performed twice during the recovery period, on Day 7 to measure early recovery (Day 87 of the study period) and on Day 35 to measure late recovery (Day 115 of the study period). The effect of low temperature and recovery on the metabolic rate was calculated by the temperature coefficient $Q_{10}$ between the $\mathrm{PC}$ and $\mathrm{C}$ periods and between the $\mathrm{C}$ and ER and LR periods (Table 4). $Q_{10}$ values of around 1.0 indicate temperature independence of the enzyme activity, while higher $Q_{10}$ values indicate higher temperature dependence and values less than 1.0 indicate negative or inverse temperature dependence. Finally, the following enzyme ratios were used to assess metabolic reorganisation in the liver (Fig. 3): the LDH/CS ratio as indicator of anaerobic component of metabo-

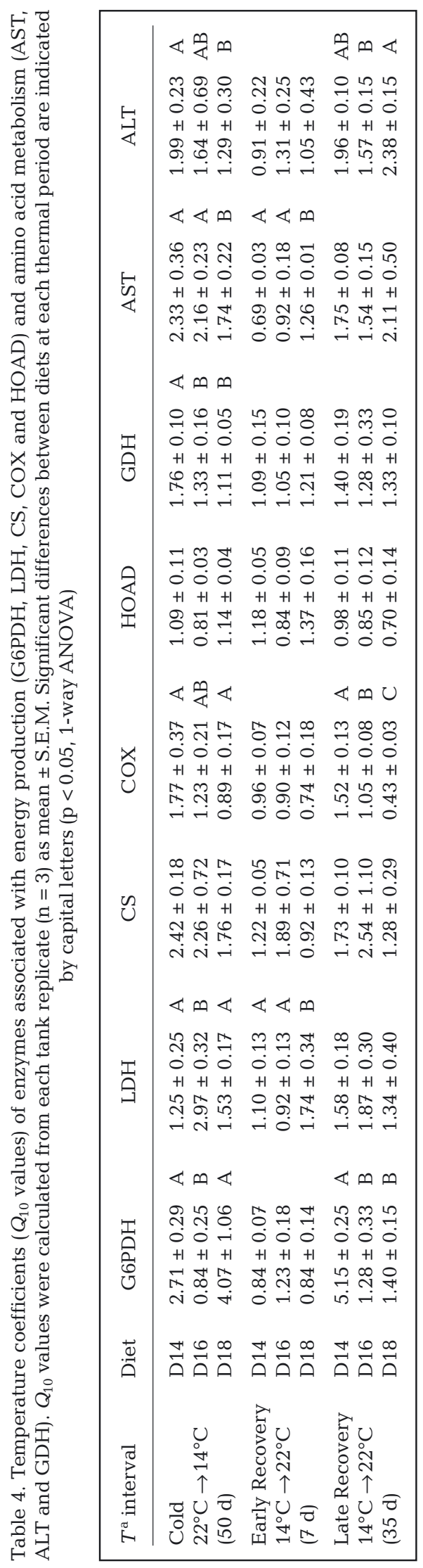



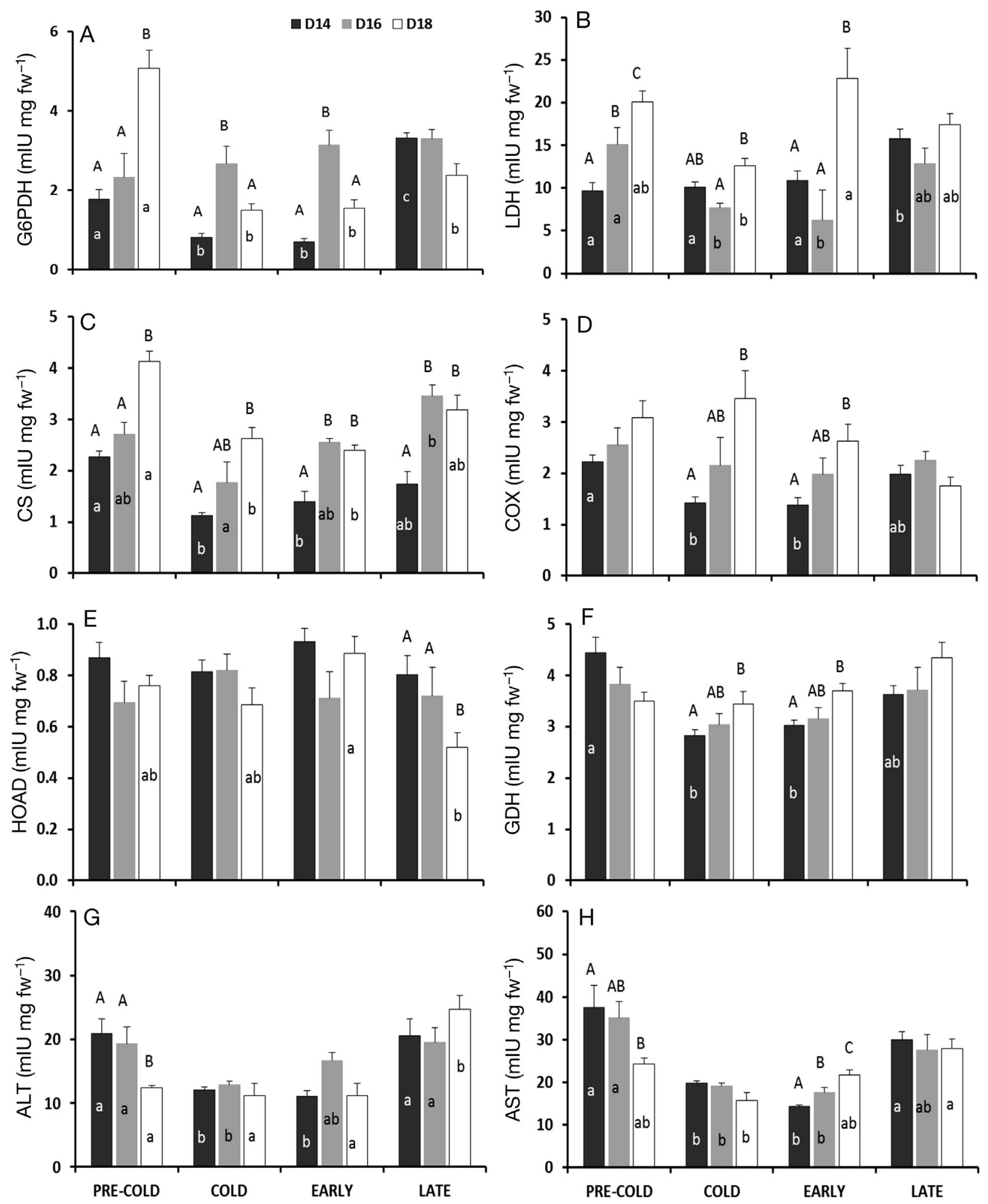

Fig. 2. Maximal activities of enzymes associated with energy production (G6PDH, LDH, CS, COX and HOAD) and amino acid metabolism (AST, ALT and GDH) in gilthead sea bream throughout temperature fluctuations. Pre-Cold: data from samples

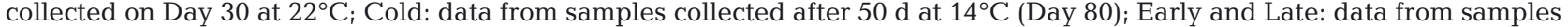
collected 7 and $35 \mathrm{~d}$ (experimental Days 87 and 115) after the start of temperature recovery to $22^{\circ} \mathrm{C}$, respectively. Lowercase letters within the bars $(\mathrm{a}, \mathrm{b}$ and $\mathrm{c})$ indicate significant differences between the periods within each diet (Tukey, $\mathrm{p}<0.05)$. Capital letters above the bars (A, B and C) indicate significant differences between the diets during each period (Tukey, $\mathrm{p}<0.05)$. D14, D16 and D18: diets containing 14, 16 and $18 \%$ lipid content respectively 

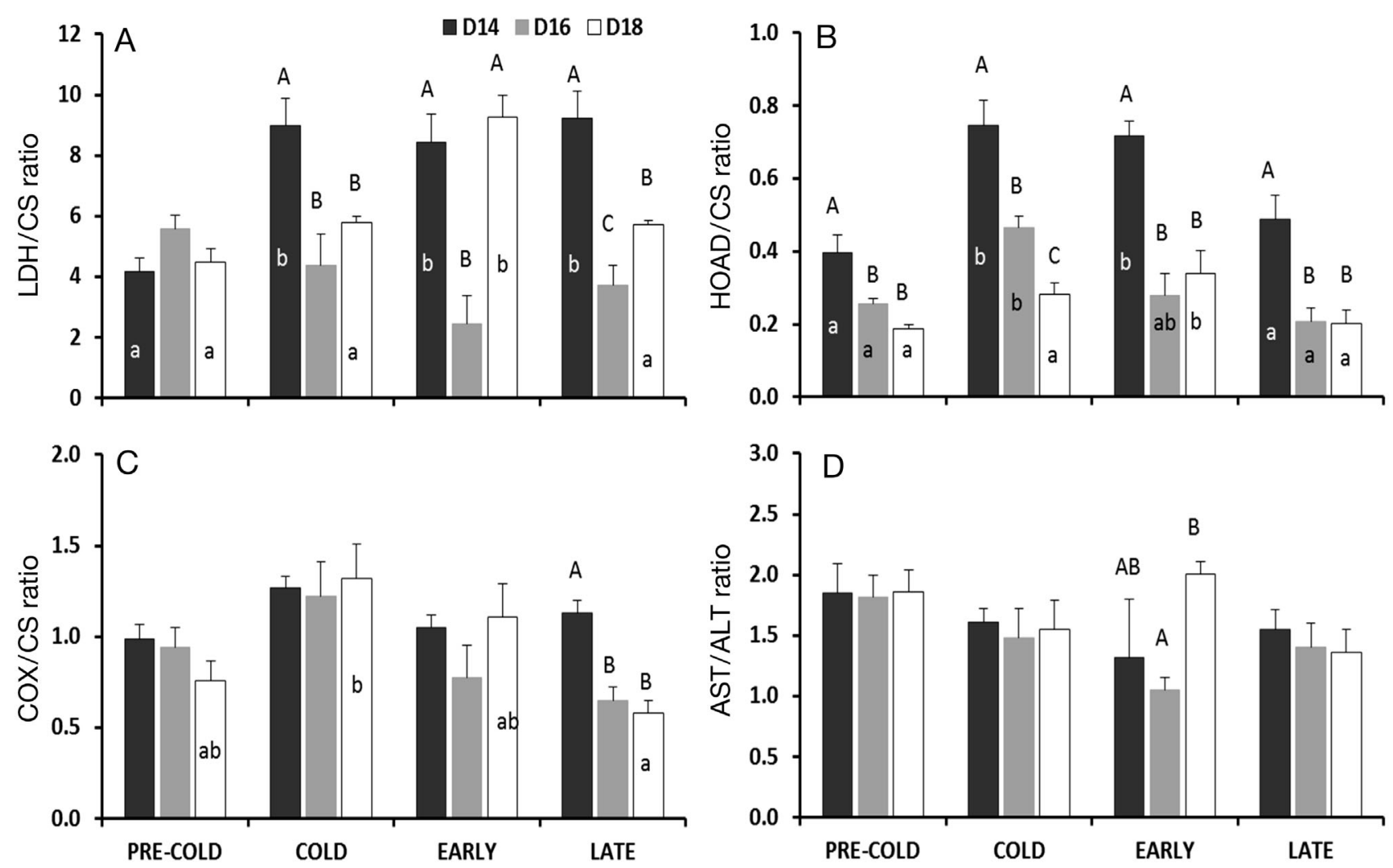

Fig. 3. Enzyme ratios in the liver of gilthead sea bream throughout temperature fluctuations. Pre-Cold: data from samples collected on Day 30 at $22^{\circ} \mathrm{C}$; Cold: data from samples collected after 50 d at $14^{\circ} \mathrm{C}$ (Day 80); Early and Late: data from samples collected 7 and $35 \mathrm{~d}$ (experimental Days 87 and 115) after the start of temperature recovery to $22^{\circ} \mathrm{C}$, respectively. Lowercase letters within the bars $(\mathrm{a}, \mathrm{b}$ and $\mathrm{c})$ indicate significant differences between the periods within each diet (Tukey, $\mathrm{p}<0.05)$. Capital letters above the bars (A, B and C) indicate significant differences between the diets during each period (Tukey, $\mathrm{p}<0.05$ ).

D14, D16 and D18: diets containing 14, 16 and 18\% lipid content respectively

lism vs. aerobic pathway; the HOAD/CS ratio for the preference for the oxidation of fuels (fatty acids vs. carbohydrates); the COX/CS ratio for mitochondrial rates; and the AST/ALT ratio for protein catabolism and liver damage.

After $30 \mathrm{~d}$ of feeding at $22^{\circ} \mathrm{C}$ during the $\mathrm{PC}$ period, the hepatic activities of G6PDH, LDH, CS and COX were greater with higher dietary lipid contents (D18 $>$ D16 > D14), whereas the activities of the hepatic transaminases (AST and ALT) and GDH were lower in the fish on the D18 diet (Tukey, $p<0.05$ ). The activity of HOAD, which is involved in $\beta$-oxidation, was not affected by dietary lipid content. Despite these differences in enzyme activities, the enzyme ratios demonstrated that the relative importance of metabolic pathways did not significantly differ between the diets, with liver metabolism adapting to the dietary condition (Fig. 3). Only the HOAD/CS ratio showed a significant difference-a 2-fold higher value in the D14-fed fish, indicating a relatively higher contribution of lipids to aerobic metabolism in these animals.
A compensatory effect through increases in enzyme activities was not observed during the $\mathrm{C}$ period. G6PDH, CS, ALT and AST activities were globally reduced in all the fish, irrespective of diet, as well as COX and GDH activities in D14-fed fish. CS and AST were the most sensitive to low temperatures, their $Q_{10}$ values increasing similarly for all 3 diets. Hence, liver metabolism was reorganised mainly in the D14-fed fish (which presented increased LDH/CS and HOAD/CS ratios) and was slightly affected in the fish on the D16 and D18 diets.

During ER, most of the enzyme activities reduced during the $\mathrm{C}$ period were not restored to initial levels, even partially, except for CS activity in D16-fed fish and LDH activity in D18-fed fish (as demonstrated by the $Q_{10}$ values of over 1.7; Table 4). During LR, enzyme activities, $Q_{10}$ values and enzyme ratios indicated the total restoration of PC liver metabolism, with the over-response of G6PDH in D14-fed fish and AST in D18-fed fish being particularly remarkable.

Fig. 4 summarises the liver intermediary metabolism at the end of each period. Most enzymes 


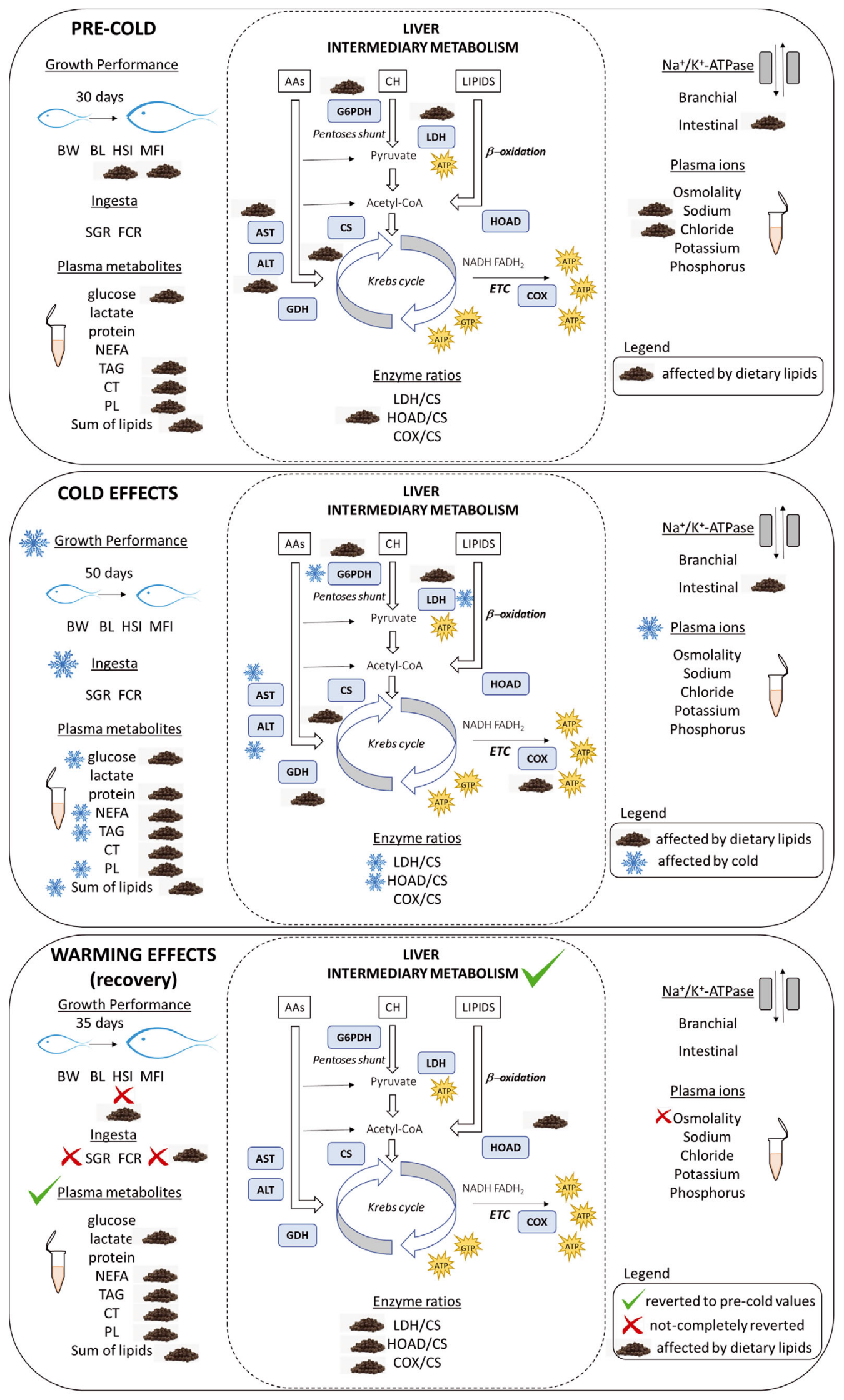

Fig. 4. Effects of diet and temperature on juvenile gilthead sea bream maintained under indoor conditions during temperature fluctuations, summarising all parameters analysed at the end of the (A) Pre-Cold; (B) Cold; and $(\mathrm{C})$ Late Recovery periods. The schematic on liver intermediary metabolism highlights the enzymes analysed. The symbol for the effects of diet indicates significant differences for a parameter between the diets, irrespective of the direction of the change. The effects of temperature are shown as: blue snowflake symbol: a significant reduction in a parameter at $14^{\circ} \mathrm{C}$ with respect to its Pre-Cold level; green tick: recovery to Pre-Cold values; red cross: incomplete reversion. See text and Tables 1 \& 2 for acronym definitions 
showed similar activities during the $\mathrm{PC}$ and recovery periods. Although differences between the diets seemed to be reduced (fewer diet symbols), important metabolic reorganisation was observed in D14fed fish due to lower CS activity, with the enzyme ratios being significantly higher than those in the D16- and D18-fed fish (Tukey, $\mathrm{p}<0.05$ ).

\section{DISCUSSION}

\section{Growth performance during temperature fluctuation}

The growth arrest during winter may last from 4 to 6 mo, and represents a critical production bottleneck for gilthead sea bream cage farming that could affect its commercial sustainability. However, there is little information on winter growth from fish farms and there are no publicly available values or reference points regarding typical parameters of growth performance. The present study is the first to simulate winter temperature fluctuations under controlled conditions to determine the effects of different dietary lipid contents. Previous studies investigating the effects of low temperatures on gilthead sea bream (reviewed in Ibarz et al. 2010a) applied 3 temperature periods to counteract negative effects: a pre-cold period, a cold period mimicking winter conditions and a temperature recovery period. The studies investigating the effects of increasing dietary lipid contents on gilthead sea bream, usually at higher temperatures, reported that lipid content alone did not significantly affect fish growth (Velázquez et al. 2006, Bonaldo et al. 2010, Mongile et al. 2014). In agreement, our results from the PC period $\left(22^{\circ} \mathrm{C}\right.$ for 30 d) suggested that reducing dietary lipid content did not affect weight gain, SGRs, feed intake or FCRs, indicating that it is possible to reduce dietary lipid content during the months before winter without detrimentally affecting fish performance, as previously stated (Ibarz et al. 2010a). We also provide, for the first time, data on gilthead sea bream growth during an extended period of a moderately cold temperature $\left(14^{\circ} \mathrm{C}\right.$ for $\left.50 \mathrm{~d}\right)$ and temperature recovery. Since gilthead sea bream individuals have been reported to stop feeding at temperatures below $13^{\circ} \mathrm{C}$ (Tort et al. 1998, Ibarz et al. 2003, 2007b), we chose the temperature of $14^{\circ} \mathrm{C}$ for the $\mathrm{C}$ period. As expected, the cold challenge induced 'winter growth arrest', with a 4 -fold decrease in the SGRs and a 2fold increase in the FCRs. Liver weight also increased, elevating the HSI and demonstrating that $14^{\circ} \mathrm{C}$ for $50 \mathrm{~d}$ did not reduce liver weight, which would have occurred with fasting at higher temperatures (Power et al. 2000, Ibarz et al. 2007a, Melis et al. 2017). To the best of our knowledge, only 2 studies have examined the effects of dietary modifications on gilthead sea bream performance during cold months. Tort et al. (2004), testing a commercial feed and a specifically prepared winter feed in indoor conditions, reported no differences in body weight gain between the diets. Silva et al. (2014), assessing the effects of a fortified diet on fish performance during a natural temperature regime in outdoor tanks, also observed growth arrest during the coldest months irrespective of diet. Tort et al. (2004) formulated a winter diet with fresh raw materials and enhanced digestibility, providing supplementary doses of vitamins $\mathrm{C}$ and $\mathrm{E}$, as well as choline and inositol. The latter study compared a low-cost commercial formulation with a high-cost commercial formulation enriched with raw materials such as fish meal and krill meal. Our study also demonstrated that reduced dietary lipid content did not affect growth parameters at lower temperatures and that fish on the lowest energy diet (D14) showed adequate performance.

Fish nourishment during the spring months after the cold season has also been poorly studied in gilthead sea bream even though higher mortality rates are observed during this period (reviewed in Ibarz et al. 2010a). A few studies have highlighted the importance of understanding the recovery mechanisms of this species after a cold fasting period at $11^{\circ} \mathrm{C}$ (Tort et al. 2004) or $8^{\circ} \mathrm{C}$ (Ibarz et al. 2007a). Moreover, Bavčević et al. (2006) studied the benefits of controlled fasting during temperature recovery, while Silva et al. (2014) indicated the importance of good raw nutrients during temperature recovery. Our data demonstrated that differences in dietary lipid contents did not modify growth parameters, although the apparent dependence of the HSI on dietary lipid content suggests the importance of higher lipid supplies during the recovery period, which is in agreement with the results of Silva et al. (2014). However, 35 d was not long enough for SGRs and FCRs to recover to their PC values, demonstrating delayed recovery from low temperatures, irrespective of dietary energy levels.

\section{Osmoregulatory response}

It is well known that suboptimal temperatures affect the osmoregulatory capacity of teleost species (Staurnes et al. 2001, Imsland et al. 2003, Metz et al. 2003, Sardella et al. 2004, 2008), including gilthead 
sea bream (Vargas-Chacoff et al. 2009a,b). Osmoregulation is influenced by food deprivation in euryhaline fish since an osmotic balance is maintained by the energy available (Sangiao-Alvarellos et al. 2003, Polakof et al. 2006). Gilthead sea bream encounter both low temperatures and cold-induced food deprivation during the course of the culture period. Vargas-Chacoff et al. (2009a), studying juvenile gilthead sea bream cultured in earthen ponds under natural photoperiod and temperature conditions, reported that plasma osmoregulation parameters (osmolality, sodium and chloride levels) showed a similar pattern of variation between the seasons, with the highest values occurring in the summer and the lowest in winter. In our experiment, fish also showed the highest values for osmolality, sodium and chloride at the higher temperature of $22^{\circ} \mathrm{C}$. Surprisingly, the osmolality values were quite high and could not be explained solely by the osmolyte concentrations. It is well known that many stressors affect the hydromineral balance in fish (Wendelaar Bonga 1997), with plasma cortisol levels the main marker for stress and other metabolites, such as glucose and lactate, being released into the plasma in response to stress (Barton 2002). Although additional stress was not expected under our indoor conditions, the high osmolality values together with relatively higher plasma glucose levels during the PC period might reflect inherent stress. Further studies are needed to evaluate, for instance, plasma cortisol levels to clarify these higher osmotic responses in gilthead sea bream maintained under indoor conditions. Similarly, high osmolarities were recorded in a different group of sea bream using a freezing point osmometer (authors' unpubl. data), which is, interestingly, in line with those observed in sea bream infected with Karlodinium spp. (Fernández-Tejedor et al. 2007). In the present study, none of the fish were affected by pathogens, with the sodium levels and especially the low chloride levels indicating no toxin-related or even temperaturerelated changes in membrane permeability.

Reduced plasma sodium and chloride concentrations at $14^{\circ} \mathrm{C}$ were in accordance with previous results obtained in controlled temperature drops (SalaRabanal et al. 2003) or in ponds (Vargas-Chacoff et al. 2009a). Plasma potassium and phosphorus levels showed opposite trends during the temperature fluctuation, but there were no differences between the dietary treatments. The highest potassium and phosphorus levels were recorded during the recovery period $\left(22^{\circ} \mathrm{C}\right)$, which were even higher than those measured during the $\mathrm{PC}$ period (also at $22^{\circ} \mathrm{C}$ ), possibly due to metabolic reorganisation.
The increased plasma potassium levels during the recovery period (by 70\% compared to initial values) should be taken into account given the importance of this ion in cellular processes. Increased potassium levels in plasma samples could be caused by contamination due to haemolysis (Mirghaed et al. 2017), which did not occur in the present study during sampling and analysis. Generally, potassium levels in fish plasma either rise or are maintained at a constant level with increasing temperature (Burton 1986). Plasma potassium levels have been reported to increase in rainbow trout just before maximum exercise, especially at elevated temperatures, as high intensity exercise elicits potassium loss from the muscle (Jain \& Farrell 2003). It is possible that the elevated potassium levels observed in sea bream during the recovery period might reflect a transient mismatch between the lack of an adequate nutritional status and the increased metabolism and overall activity induced by the rise in temperature.

Changes in the osmoregulatory capacity in fish exposed to low temperatures have been associated with alterations in relevant tissues such as the gills, kidneys and intestines. Generally, fish increase $\mathrm{Na}^{+} / \mathrm{K}^{+}$-ATPase activity in the gills to cope with low temperatures (Gabbianelli et al. 1996, Packer \& Garvin 1998, Imsland et al. 2003, Metz et al. 2003). However, Vargas-Chacoff et al. (2009a) and Ibarz et al. (2010a) could not confirm this in sea bream. We did not observe changes in branchial and intestinal $\mathrm{Na}^{+} / \mathrm{K}^{+}$-ATPase activities in response to low temperatures. Such changes in activities have been observed to be accompanied by morphological modifications, such as reduced numbers of apical membrane microvilli and chloride cells (Ibarz et al. 2010a) in the first days of a cold challenge at $8^{\circ} \mathrm{C}$. However, temperature maintenance at $8^{\circ} \mathrm{C}$ for $20 \mathrm{~d}$ has been reported to partially reverse the changes and cause homeoviscous adaptation that increases membrane unsaturation (Ibarz et al. 2005). The rapid and necessary recovery of crucial ATPase activity could explain why low temperatures did not significantly affect both branchial and intestinal ATPase activities in the present study. Additionally, branchial $\mathrm{Na}^{+} / \mathrm{K}^{+}$ATPase activity was already rather low, even at $22^{\circ} \mathrm{C}$, compared to other studies on sea bream (LaizCarrión et al. 2005, Vargas-Chacoff et al. 2009a), which might be partly related to the high plasma osmolality and, thus, a reduced gradient with external water.

In contrast to branchial $\mathrm{Na}^{+} / \mathrm{K}^{+}$-ATPase activity, intestinal $\mathrm{Na}^{+} / \mathrm{K}^{+}$-ATPase activities were variable and showed diet-related differences. Although die- 
tary lipid levels did not affect the overall osmoregulatory capacity, intestinal $\mathrm{Na}^{+} / \mathrm{K}^{+}$-ATPase activity was lower (2- to 3-fold) in D14-fed fish than in D16- and D18-fed fish during the PC period. The activity of ouabain-sensitive intestinal $\mathrm{Na}^{+} / \mathrm{K}^{+}$-ATPase in sea bream is segment-dependent and related to both ion osmoregulation and nutritional processes (Díaz et al. 1998, Almansa et al. 2001, Gregório et al. 2013). It has an Arrhenius breakpoint temperature at around $15^{\circ} \mathrm{C}$, but with similarly low activation energies above and below the discontinuity (Díaz et al. 1998). This temperature is close to the lowest temperature used in our study, which might explain the lack of changes in enzyme activities between the temperature periods. Since we observed no significant differences in the osmotic parameters, $\mathrm{Na}^{+} / \mathrm{K}^{+}$-ATPase activity could indirectly reflect the intestinal absorption ability of fish, as some nutrients (amino acids and glucose) are absorbed in association with $\mathrm{Na}^{+}$via the action of $\mathrm{Na}^{+} / \mathrm{K}^{+}$-ATPases (Rhoads et al. 1994, Klein et al. 1998). In this sense, a medium energy diet would favour absorption. However, the absence of significant differences in growth parameters does not support the notion that changes in intestinal $\mathrm{Na}^{+} / \mathrm{K}^{+}$ATPase activity caused major diet-specific changes, and further studies are required to tackle the relationship between dietary energy levels and $\mathrm{Na}^{+} / \mathrm{K}^{+}$ATPase activity. It is known, however, that the polar lipid fatty acid composition of the intestinal mucosa correlates with the Arrhenius plot breakpoint, suggesting a regulatory role of the lipid microenvironment on enzyme activity (Díaz et al. 1998) and that enterocytes are susceptible to diet-induced lipid alterations (Díaz et al. 2016).

\section{Metabolic reorganisation}

Blood analysis is performed routinely to evaluate physiological changes in mammals (Knox et al. 1998). Recently, several plasma metabolites and enzymes were used to evaluate the nutritional status of healthy juvenile gilthead sea bream (Peres et al. 2013). Here, we analysed glucose, lactate, protein and lipid fractions, which are strongly associated with responses to low temperatures in gilthead sea bream (reviewed in Ibarz et al. 2010a). During the PC period, plasma levels of TAG, PL and TC inversely correlated with dietary lipid content, the sum of plasma lipids being the highest in the D14-fed fish and reflecting pre-feeding levels (Polakof et al. 2007). Thus, plasma lipid fractions are more precise indicators of nutritional status than glucose or pro- teins at $22^{\circ} \mathrm{C}$, as suggested by Peres et al. (2013) in their study of nutritional statuses.

It is well known that acute cold shock (from 18 to $8^{\circ} \mathrm{C}$ ) induces both hyperglycaemia (Sala-Rabanal et al. 2003) and hyperlipidaemia (Ibarz et al. 2007a). Higher glucose levels and cortisol secretion have been linked to stress (Rotllant et al. 2001), while higher lipid levels have been associated with the release of lipids from perivisceral fat (Ibarz et al. 2007a). Although we observed hyperlipidaemia in fish on the D14 and D16 diets during the C period, glycaemia decreased 2-fold, irrespective of diet. These changes were reverted when the water temperature increased. Our results are in agreement with the annual inverse variation in plasma glucose and TAG levels reported by Vargas-Chacoff et al. (2009a), who noted that the highest glucose levels and lowest TAG levels occurred during the summer and the opposite during winter. The low glucose levels at low temperatures might be due to a decrease in the capacity of the liver to produce glucose, while higher lipid levels have been linked to reduced feeding and increased mobilisation of lipid stores (Vargas-Chacoff et al. 2009b, Ibarz et al. 2010a). The transitory changes in TAG and glucose levels in response to low temperatures can therefore be used as indicators of a cold challenge.

Liver function has been widely examined in studies investigating cold challenges due to its importance in blood composition and osmo/ion regulation, immune function, reproduction, detoxification and many other processes related to energy metabolism. We focused on the capacity of the liver to recover from low temperatures, analysing key enzymes of intermediary metabolism, their temperature coefficients $\left(Q_{10}\right)$ and ratios that could be used to indicate metabolic reorganisation. Feidantsis et al. (2018), under culture conditions, reported seasonal metabolic patterns involving oxidative stress during the summer and winter. Lipid oxidation is induced by low temperatures, while metabolic activation and carbohydrate oxidation are also elicited at higher temperatures. Accordingly, the glutathione redox cycle and liver antioxidant enzyme activities have been reported to be strongly affected by low temperatures under indoor conditions (Sánchez-Nuño et al. 2018). Evaluating metabolic patterns when dietary lipid intake was reduced, our results from the PC period demonstrated that dietary lipids modified hepatic enzyme activities according to energy intake, as expected for sea bream at $22^{\circ} \mathrm{C}$. Diets with higher lipid contents were associated with higher activities of energy-related enzymes (CS, COX and LDH) and lower activities 
of enzymes involved with amino acid metabolism (AST, ALT and GDH), possibly to preserve amino acids for use as energy fuel. G6PDH activity also increased with higher dietary lipid intake. In general, liver G6PDH activity in fish increases with food availability to provide NADPH (Bastrop et al. 1992), which is essential for reductive biosynthesis, nucleic acid synthesis and cell protection against oxidants. The clearly increased metabolism in the livers of D18-fed fish would involve higher free radical production and more oxidant attacks. Thus, higher G6PDH activity would provide the reducing power for the antioxidant system. Sánchez-Nuño et al. (2018) reported that reducing dietary lipid content from 18 to $14 \%$ lowered oxidised lipid levels by half in both the plasma and liver of gilthead sea bream, thereby decreasing the putative effects of lipid peroxidation at $22^{\circ} \mathrm{C}$. Surprisingly, we did not observe lipid dependency for HOAD activity despite this enzyme being directly associated with lipid catabolism. Usually, fish fed high-fat diets show increased levels of mitochondrial HOAD (Antonopoulou et al. 2014, Librán-Pérez et al. 2015). Our results therefore suggest that liver lipid metabolism was not affected by a $4 \%$ reduction in dietary lipid content. However, using enzyme ratios as indicators of metabolic reorganisation, we did observe that the HOAD/CS ratio was higher in the fish on the D14 diet than in those on the D16 and D18 diets, indicating that lipid entry into the Krebs cycle was greater in D14-fed fish. The preference for fatty acid vs. carbohydrate oxidation and the mitochondrial index (the COX/CS ratio) were similar, irrespective of diet, demonstrating the high plasticity of liver metabolism at $22^{\circ} \mathrm{C}$. Considering all the data on growth, ingesta, plasma metabolites, the osmoregulatory capacity and liver metabolism (see Fig. 4), a $4 \%$ reduction in dietary lipid content did not affect fish growth, and metabolism was modulated accordingly in gilthead sea bream grown indoors.

We have studied changes in the metabolic rate (Ibarz et al. 2003), liver composition and enzyme activities in gilthead sea bream exposed to low temperatures (Ibarz et al. 2007a, 2010b,c), which have demonstrated that this species has little capacity to acclimate to temperatures under $12-13^{\circ} \mathrm{C}$. Exposing sea bream to $14^{\circ} \mathrm{C}$ for an extended period (50 d) revealed their inability to compensate for low temperatures in their enzyme activities, even when feeding. Moreover, some enzymes, such as G6PDH, CS, AST and ALT, showed greatly reduced activities, as previously reported for lower temperatures (Ibarz et al. 2010b). Several studies, evaluating annual chan- ges in glucose intermediary metabolism in caged adult gilthead sea bream (Gómez-Milán et al. 2007) and the osmoregulatory and metabolic capacities of immature animals in earthen ponds (Vargas-Chacoff et al. 2009a), reported the lack of seasonal changes in the activities of fructose 1,6-bisphosphatase (FBPase), AST, pyruvate kinase (Gómez-Milán et al. 2007), FPBase and G6PDH (Vargas-Chacoff et al. 2009a). Indoor studies in which animals were exposed to 12 , 19 and $26^{\circ} \mathrm{C}$ for $35 \mathrm{~d}$ (Vargas-Chacoff et al. 2009b) and to 8 or $12^{\circ} \mathrm{C}$ (Ibarz et al. 2007b), corroborated the lack of compensation in enzyme activities during temperature acclimation. The concomitant increase in LDH and CS activities also indicated an increased conversion of carbohydrates into lactate.

The current study aimed to further analyse the effects of reducing dietary lipid content during a cold challenge, evaluating temperature coefficients and metabolic ratio indicators. Our group recently reported a lack of acclimation of antioxidant enzymes to low temperatures $\left(14^{\circ} \mathrm{C}\right)$ and increased levels of oxidised proteins in animals fed higher dietary lipids (Sánchez-Nuño et al. 2018), which are consistent with the increased oxidised lipids during the cold season reported by Feidantsis et al. (2018). G6PDH activity in D18-fed fish was strongly affected, with a $Q_{10}$ of around 4 , which, together with lower glutathione levels at low temperatures (Sánchez-Nuño et al. 2018), indicated that diets with higher lipid contents are not recommendable for low temperatures. The $Q_{10}$ values demonstrated that the overall decrease in enzyme activity did not show a similar pattern for all the diets. For example, G6PDH, CS, AST and ALT activities decreased by half in D14-fed fish. Kyprianou et al. (2010) reported that LDH and HOAD activities increased in sea bream maintained at low temperatures, suggesting increased anaerobic metabolism together with higher oxidation of free fatty acids that contributed to ATP turnover. These changes elicit a reorganisation of liver metabolism, which was highly evident in D14-fed fish via the increased LDH/CS and HOAD/CS ratios.

To better understand the recovery in liver metabolism from low temperatures and reduced dietary intake, we performed 2 samplings during the recovery period. Feidantsis et al. (2015) reported tissuedependent and time-dependent responses of $\mathrm{LDH}_{\text {, }}$ HOAD and CS activities to acute warming in gilthead sea bream. For example, during a transition from 18 to $24^{\circ} \mathrm{C}, \mathrm{HOAD}$ and $\mathrm{CS}$ activities increased and $\mathrm{LDH}$ activity decreased during the first week, indicating enhanced liver aerobic metabolism in response to an increased energy demand. Our results 
indicated that the recovery from lower temperatures was different from acute warming in sea bream. The decreased enzyme activities were still not restored $7 \mathrm{~d}$ after the start of temperature recovery, with $Q_{10}$ values still near 1 and only LDH activity for D18-fed fish and CS activity for D16-fed fish showing higher $Q_{10}$ values. The higher LDH activity in D18-fed fish increased the LDH/CS ratio, which indicated the uncoupling of anaerobic processes during the first days of recovery. The higher CS activity in D16-fed fish suggested that this diet was more favourable during early recovery. At $35 \mathrm{~d}$ after the start of temperature recovery (LR), most of the enzyme activities had reverted to their PC levels, showing the delay in the recovery process. Since enzyme activities were presented per mg of fresh liver weight, and given that the HSI was 2-fold lower in D14-fed fish than in D18-fed fish, the D14 diet could further affect liver capacities, considerably reducing 'enzymatic power' during recovery from low temperatures. Moreover, it has been reported that the glutathione redox cycle is not fully restored after recovery from $50 \mathrm{~d}$ at $14^{\circ} \mathrm{C}$, with fish on the low-lipid diet presenting higher liver protein oxidation than those on diets with higher lipid contents (Sánchez-Nuño et al. 2018). Thus, although fish growth was not significantly affected, the D14 diet did not adequately meet the energy demands for the recovery from low temperatures.

\section{CONCLUSIONS}

Reducing dietary lipids, and consequently, dietary energy, did not affect gilthead sea bream performance during temperature fluctuation in indoor conditions. However, to cope with low temperatures in culture, we propose different diets for the pre-cold, cold and recovery periods based on real energy needs. We recommend diets with reduced lipid contents during the pre-cold and cold culture periods, especially since high dietary energy levels and culture densities have been reported to have deleterious effects on physiology and growth in other fish species (Suárez et al. 2015). Although cold-induced growth arrest and metabolic depression are unavoidable, a well-formulated low-lipid diet would be enough to meet the low energy demands at low temperatures. The recovery from low temperatures is different from acute warming in sea bream and requires diets with increased energy contents to guarantee good liver condition, and mineral supplementation to maintain osmoregulation and bone formation. Furthermore, higher protein contents are desirable to improve tis- sue restoration and possibly improve growth during recovery from low temperatures. However, further studies are needed to comprehensively assess the temperature recovery period and the dietary needs of gilthead sea bream in commercial cage culture conditions.

Acknowledgements. This study was supported by a grant from the Spanish government (AGL2011-29873), and by the FTC foundation grants from the Portuguese government (UID/Multi/04326 and PTDC/BIA-ANM/4225/2012). O.T.E. and I.Ö. received fellowships from the Erasmus Turkish Program.

\section{LITERATURE CITED}

Almansa E, Sanchez J, Cozzi S, Casariego M, Cejas J, Díaz M (2001) Segmental heterogeneity in the biochemical properties of the $\mathrm{Na}^{+}-\mathrm{K}^{+}$-ATPase along the intestine of the gilthead seabream (Sparus aurata L.). J Comp Physiol B 171:557-567

Antonopoulou E, Kousidou E, Tserga E, Feidantsis K, Chatzifotis S (2014) Dietary lipid levels in meagre (Argyrosomus regius): effects on biochemical and molecular indicators of liver. Aquaculture 428-429:265-271

Barnabé G (1990) Rearing bass and gilthead sea bream. Aquaculture 2:647-686

Barton BA (2002) Stress in fishes: a diversity of responses with particular reference to changes in circulating corticosteroids. Integr Comp Biol 42:517-525

*Bastrop R, Jürss K, Wacke R (1992) Biochemical parameters as a measure of food availability and growth in immature rainbow trout (Oncorhynchus mykiss). Comp Biochem Physiol A 102:151-161

Bavčević L, Petrovi S, Crnica M, Corazzin E (2006) Effects of feeding strategy on growth of sea bream (Sparus aurata L.) during winter-spring and possible implications for "winter disease" syndrome. Ribarstvo 64:1-17

Blasco J, Moya A, Millán-Cubillo A, Vélez EJ and others (2015) Growth-promoting effects of sustained swimming in fingerlings of gilthead sea bream (Sparus aurata L.). J Comp Physiol B 185:859-868

Bonaldo A, Isani G, Fontanillas R, Parma L, Grilli E, Gatta PP (2010) Growth and feed utilization of gilthead sea bream (Sparus aurata, L.) fed to satiation and restrictively at increasing dietary energy levels. Aquacult Int 18: 909-919

Bradford MM, Williams WL (1976) New, rapid, sensitive method for protein determination. Fed Proc 35:274

* Burton RF (1986) Ionic regulation in fish: the influence of acclimation temperature on plasma composition and apparent set points. Comp Biochem Physiol A 85:23-28

* Díaz M, Cozzi S, Almansa E, Casariego M, Bolaños A, Cejas J, Lorenzo A (1998) Characterization of intestinal $\mathrm{Na}^{+}$$\mathrm{K}^{+}$-ATPase in the gilthead seabream (Sparus aurata L.). Evidence for a tissue-specific heterogeneity. Comp Biochem Physiol B Biochem Mol Biol 121:65-76

* Díaz M, Dópido R, Gómez T, Rodríguez C (2016) Membrane lipid microenvironment modulates thermodynamic properties of the $\mathrm{Na}^{+}-\mathrm{K}^{+}$-ATPase in branchial and intestinal epithelia in euryhaline fish in vivo. Front Physiol 7:589

Donaldson MR, Cooke SJ, Patterson DA, Macdonald JS 
(2008) Cold shock and fish. J Fish Biol 73:1491-1530

Feidantsis K, Pörtner HO, Antonopoulou E, Michaelidis B (2015) Synergistic effects of acute warming and low $\mathrm{pH}$ on cellular stress responses of the gilthead seabream Sparus aurata. J Comp Physiol B 185:185-205

Feidantsis K, Pörtner HO, Vlachonikola E, Antonopoulou E, Michaelidis B (2018) Seasonal changes in metabolism and cellular stress phenomena in the gilthead sea bream (Sparus aurata). Physiol Biochem Zool 91:878-895

Fernández-Tejedor M, Soubrier-Pedreño M, Furones M (2007) Mitigation of lethal effects of Karlodinium veneficum and $K$. armiger on Sparus aurata: changes in haematocrit and plasma osmolality. Dis Aquat Org 77: 53-59

Furné M, García-Gallego M, Hidalgo MC, Morales AE, Domezain A, Domezain J, Sanz A (2009) Oxidative stress parameters during starvation and refeeding periods in Adriatic sturgeon (Acipenser naccarii) and rainbow trout (Oncorhynchus mykiss). Aquacult Nutr 15:587-595

Gabbianelli R, Falcioni G, Mazzanti L, Bertoli E, Zolese G (1996) Seasonal variations of physical and biochemical membrane properties in trout erythrocytes (Salmo irideus). Comp Biochem Physiol B Biochem Mol Biol 114: 275-279

Gómez-Milán E, Cardenete G, Sánchez-Muros MJ (2007) Annual variations in the specific activity of fructose 1,6-bisphosphatase, alanine aminotransferase and pyruvate kinase in the Sparus aurata liver. Comp Biochem Physiol B Biochem Mol Biol 147:49-55

* Gregório SF, Carvalho ESM, Encarnação S, Wilson JM, Power DM, Canário AVM, Fuentes J (2013) Adaptation to different salinities exposes functional specialization in the intestine of the sea bream (Sparus aurata L.). J Exp Biol 216:470-479

Hurst TP (2007) Causes and consequences of winter mortality in fishes. J Fish Biol 71:315-345

I Ibarz A, Fernández-Borràs J, Blasco J, Gallardo MA, Sánchez J (2003) Oxygen consumption and feeding rates of gilthead sea bream (Sparus aurata) reveal lack of acclimation to cold. Fish Physiol Biochem 29:313-321

Ibarz A, Blasco J, Beltrán M, Gallardo MA, Sánchez J, Sala R, Fernández-Borràs J (2005) Cold-induced alterations on proximate composition and fatty acid profiles of several tissues in gilthead sea bream (Sparus aurata). Aquaculture 249:477-486

Ibarz A, Blasco J, Sala-Rabanal M, Gallardo Á, Redondo A, Fernández-Borràs J (2007a) Metabolic rate and tissue reserves in gilthead sea bream (Sparus aurata) under thermal fluctuations and fasting and their capacity for recovery. Can J Fish Aquat Sci 64:1034-1042

* Ibarz A, Beltrán M, Fernández-Borràs J, Gallardo MA, Sánchez J, Blasco J (2007b) Alterations in lipid metabolism and use of energy depots of gilthead sea bream (Sparus aurata) at low temperatures. Aquaculture 262: $470-480$

* Ibarz A, Padrós F, Gallardo MÁ, Fernández-Borràs J, Blasco J, Tort L (2010a) Low-temperature challenges to gilthead sea bream culture: review of cold-induced alterations and 'Winter Syndrome.'. Rev Fish Biol Fish 20:539-556

* Ibarz A, Martín-Pérez M, Blasco J, Bellido D, de Oliveira E, Fernández-Borràs J (2010b) Gilthead sea bream liver proteome altered at low temperatures by oxidative stress. Proteomics 10:963-975

Ibarz A, Blasco J, Gallardo MÁ, Fernández-Borràs J (2010c) Energy reserves and metabolic status affect the acclima- tion of gilthead sea bream (Sparus aurata) to cold. Comp Biochem Physiol A Mol Integr Physiol 155:319-326

* Imsland AK, Gunnarsson S, Foss A, Stefansson SO (2003) Gill $\mathrm{Na}^{+}, \mathrm{K}^{+}$-ATPase activity, plasma chloride and osmolality in juvenile turbot (Scophthalmus maximus) reared at different temperatures and salinities. Aquaculture 218:671-683

Jain KE, Farrell AP (2003) Influence of seasonal temperature on the repeat swimming performance of rainbow trout Oncorhynchus mykiss. J Exp Biol 206:3569-3579

Klein S, Cohn SM, Alpers DH (1998) The alimentary tract in nutrition. In: Shils ME, Olson AJ, Shike M, Ross AC (eds) Modern nutrition in health and disease. Williams \& Wilkins, Baltimore, MD, p 605-630

Knox SS, Siegmund KD, Weidner G, Ellison RC, Adelman A, Paton C (1998) Hostility, social support, and coronary heart disease in the National Heart, Lung, and Blood Institute Family Heart Study. Am J Cardiol 82:1192-1196

Kyprianou TD, Pörtner HO, Anestis A, Kostoglou B, Feidantsis K, Michaelidis B (2010) Metabolic and molecular stress responses of gilthead seam bream Sparus aurata during exposure to low ambient temperature: an analysis of mechanisms underlying the winter syndrome. J Comp Physiol B 180:1005-1018

* Laiz-Carrión R, Guerreiro PM, Fuentes J, Canario AVM, Martín del Río MP, Mancera JM (2005) Branchial osmoregulatory response to salinity in the gilthead sea bream, Sparus auratus. J Exp Zoolog A Comp Exp Biol 303A: 563-576

* Librán-Pérez M, Geurden I, Dias K, Corraze G, Panserat S, Soengas JL (2015) Feeding rainbow trout with a lipidenriched diet: effects on fatty acid sensing, regulation of food intake and cellular signaling pathways. J Exp Biol 218:2610-2619

* Mancera JM, Laiz-Carrión R, Martín Del Río MP (2002) Osmoregulatory action of PRL, GH, and cortisol in the gilthead seabream (Sparus aurata L.). Gen Comp Endocrinol 129:95-103

*Martin-Perez M, Fernandez-Borras J, Ibarz A, MillanCubillo A, Felip O, de Oliveira E, Blasco J (2012) New insights into fish swimming: a proteomic and isotopic approach in gilthead sea bream. J Proteome Res 11: 3533-3547

McCormick SD (1993) Methods for nonlethal gill biopsy and measurement of $\mathrm{Na}^{+}, \mathrm{K}^{+}$-ATPase activity. Can J Fish Aquat Sci 50:656-658

Melis R, Sanna R, Braca A, Bonaglini E and others (2017) Molecular details on gilthead sea bream (Sparus aurata) sensitivity to low water temperatures from ${ }^{1} \mathrm{H}$ NMR metabolomics. Comp Biochem Physiol A Mol Integr Physiol 204:129-136

Metz JR, van den Burg EH, Bonga SEW, Flik G (2003) Regulation of branchial $\mathrm{Na}^{+} / \mathrm{K}^{+}$-ATPase in common carp Cyprinus carpio L. acclimated to different temperatures. J Exp Biol 206:2273-2280

Mirghaed AT, Ghelichpour M, Hoseini SM, Amini K (2017) Hemolysis interference in measuring fish plasma biochemical indicators. Fish Physiol Biochem 43:1143-1151

Mongile F, Bonaldo A, Fontanillas R, Mariani L, Badiani A, Bonvini E, Parma L (2014) Effects of dietary lipid level on growth and feed utilisation of gilthead seabream (Sparus aurata L.) reared at Mediterranean summer temperature. Ital J Anim Sci 13:2999

* Packer RK, Garvin JL (1998) Seasonal differences in activity of perch (Perca flavescens) gill $\mathrm{Na}^{+} / \mathrm{K}^{+}$ATPase. Comp 
Biochem Physiol B Biochem Mol Biol 120:777-783

Peres H, Santos S, Oliva-Teles A (2013) Selected plasma biochemistry parameters in gilthead seabream (Sparus aurata) juveniles. J Appl Ichthyology 29:630-636

Polakof S, Arjona FJ, Sangiao-Alvarellos S, Martín del Río MP, Mancera JM, Soengas JL (2006) Food deprivation alters osmoregulatory and metabolic responses to salinity acclimation in gilthead sea bream Sparus auratus. J Comp Physiol B 176:441-452

Polakof S, Míguez JM, Soengas JL (2007) Daily changes in parameters of energy metabolism in liver, white muscle, and gills of rainbow trout: dependence on feeding. Comp Biochem Physiol A Mol Integr Physiol 147:363-374

Power DM, Melo J, Santos CRA (2000) The effect of food deprivation and refeeding on the liver, thyroid hormones and transthyretin in sea bream. J Fish Biol 56:374-387

Prosser CL (ed) (1991) Environmental and metabolic animal physiology. In: Prosser CL (ed) Comparative animal physiology, 4th edn. University of Illinois, p 109-165

Ravagnan G (1978) Elementi di vallicoltura moderna; proposte operative per la ristrutturazione e lo sviluppo della itticoltura salmastra italiana. Edagricole, Bologna

Rhoads JM, Chen W, Chu P, Berschneider HM, Argenzio RA, Paradiso AM (1994) L-glutamine and L-asparagine stimulate $\mathrm{NA}^{+}-\mathrm{H}^{+}$exchange in porcine jejunal enterocytes. Am J Physiol 266:G828-G838

Rotllant J, Balm PHM, Pérez-Sánchez J, Wendelaar-Bonga SE, Tort L (2001) Pituitary and interrenal function in gilthead sea bream (Sparus aurata L., Teleostei) after handling and confinement stress. Gen Comp Endocrinol 121: 333-342

Sala-Rabanal M, Sanchez J, Ibarz A, Fernandez-Borras J, Blasco J, Gallardo MA (2003) Effects of low temperatures and fasting on hematology and plasma composition of gilthead sea bream (Sparus aurata). Fish Physiol Biochem 29:105-115

Sánchez-Nuño S, Sanahuja I, Ferández-Alacid L, OrdóñezGrande B and others (2018) Redox challenge in a cultured temperate marine species during low temperature and temperature recovery. Front Physiol 9:923

Sangiao-Alvarellos S, Laiz-Carrión R, Guzmán JM, Martín del Río MP, Miguez JM, Mancera JM, Soengas JL (2003) Acclimation of $S$. aurata to various salinities alters energy metabolism of osmoregulatory and nonosmoregulatory organs. Am J Physiol Regul Integr Comp Physiol 285: R897-R907

Sardella BA, Matey V, Cooper J, Gonzalez RJ, Brauner CJ (2004) Physiological, biochemical and morphological indicators of osmoregulatory stress in 'California' Mozambique tilapia (Oreochromis mossambicus x O. urolepis hornorum) exposed to hypersaline water. J Exp Biol 207: 1399-1413

Editorial responsibility: Gianluca Sará,

Palermo, Italy
Sardella BA, Sanmarti E, Kültz D (2008) The acute temperature tolerance of green sturgeon (Acipenser medirostris) and the effect of environmental salinity. J Exp Zool Part A Ecol Genet Physiol 309A:477-483

Sarusic G (1999) Clinical signs of the winter disease phenomenon in sea bream (Sparus aurata, L.). Bull Eur Assoc Fish Pathol 19:113

* Silva TS, da Costa AMR, Conceição LEC, Dias JP, Rodrigues PML, Richard N (2014) Metabolic fingerprinting of gilthead seabream (Sparus aurata) liver to track interactions between dietary factors and seasonal temperature variations. PeerJ 2:e527

* Srere PA (1969) [1] Citrate synthase: [EC 4.1.3.7. Citrate oxaloacetate-lyase (CoA-acetylating)]. Methods Enzymol 13:3-11

* Staurnes M, Sigholt T, Åsgård T, Baeverfjord G (2001) Effects of a temperature shift on seawater challenge test performance in Atlantic salmon (Salmo salar) smolt. Aquaculture 201:153-159

* Suárez MD, Trenzado CE, García-Gallego M, Furné M and others (2015) Interaction of dietary energy levels and culture density on growth performance and metabolic and oxidative status of rainbow trout (Oncorhynchus mykiss). Aquacult Eng 67:59-66

* Toranzo AE, Magariños B, Romalde JL (2005) A review of the main bacterial fish diseases in mariculture systems. Aquaculture 246:37-61

* Tort L, Rotllant J, Rovira L (1998) Immunological suppression in gilthead sea bream Sparus aurata of the NorthWest Mediterranean at low temperatures. Comp Biochem Physiol A Mol Integr Physiol 120:175-179

* Tort L, Rotllant J, Liarte C, Acerete L and others (2004) Effects of temperature decrease on feeding rates, immune indicators and histopathological changes of gilthead sea bream Sparus aurata fed with an experimental diet. Aquaculture 229:55-65

Vargas-Chacoff L, Arjona FJ, Ruiz-Jarabo I, Páscoa I, Gonçalves O, Martín del Río MP, Mancera JM (2009a) Seasonal variation in osmoregulatory and metabolic parameters in earthen pond-cultured gilthead sea bream Sparus auratus. Aquacult Res 40:1279-1290

*Vargas-Chacoff L, Arjona FJ, Polakof S, Martín del Río MP, Soengas JL, Mancera JM (2009b) Interactive effects of environmental salinity and temperature on metabolic responses of gilthead sea bream Sparus aurata. Comp Biochem Physiol A Mol Integr Physiol 154:417-424

Velázquez M, Zamora S, Martínez FJ (2006) Effect of dietary energy content on gilthead sea bream (Sparus aurata) feeding behaviour and nutritional use of the diet. Aquacult Nutr 12:127-133

Wendelaar Bonga SE (1997) The stress response in fish. Physiol Rev 77:591-625

Submitted: March 19, 2018; Accepted: September 23, 2018 Proofs received from author(s): November 20, 2018 